\title{
Why do we think that inflation expectations matter for inflation? (And should we?)
}

\author{
Jeremy B. Rudd* \\ Federal Reserve Board, Washington, DC, USA
}

Economists and economic policymakers believe that households' and firms' expectations of future inflation are a key determinant of actual inflation. A review of the relevant theoretical and empirical literature suggests that this belief rests on extremely shaky foundations, and a case is made that adhering to it uncritically could easily lead to serious policy errors.

Keywords: inflation dynamics, wage determination

JEL codes: $E 31, J 30$

'Nobody thinks clearly, no matter what they pretend. ... That's why people hang on so tight to their beliefs and opinions; because, compared to the haphazard way they're arrived at, even the goofiest opinion seems wonderfully clear, sane, and self-evident.'

Dashiell Hammett, The Dain Curse (1928 [1989], p. 181)

\section{INTRODUCTION}

Mainstream economics is replete with ideas that 'everyone knows' to be true, but that are actually arrant nonsense. For example, 'everyone knows' that:

- aggregate production functions (and aggregate measures of the capital stock) provide a good way to characterize the economy's supply side;

- over a sufficiently long span - specifically, one that allows necessary price adjustments to be made - the economy will return to a state of full market clearing; and

- the theory of household choice provides a solid justification for downward-sloping market demand curves.

None of these propositions has any sort of empirical foundation; moreover, each one turns out to be seriously deficient on theoretical grounds. ${ }^{1}$ Nevertheless, economists continue to rely on these and similar ideas to organize their thinking about real-world economic phenomena. No doubt one reason why this situation arises is

* The analysis and conclusions set forth are my own and do not necessarily reflect the views of the Board of Governors or the staff of the Federal Reserve System.

1. For a useful brief against production functions, see Felipe and Fisher (2003); for the case against capital aggregates, see Brown (1980). The idea that the inherent stability of the economy is a concomitant of general-equilibrium theory is difficult to entertain seriously after giving Fisher (1983) close study; see Grandmont (1982) for some related macroeconomic arguments. Finally, Hildenbrand (1994) provides a sobering corrective to first-year demand theory. 
because the economy is a complicated system that is inherently difficult to understand, so propositions like these - even though wrong - are all that saves us from intellectual nihilism. Another, more prosaic reason is Stigler's (1983, p. 541) equally nihilistic observation that 'it takes a theory to beat a theory.'

Is this state of affairs ever harmful or dangerous? One natural source of concern is if dubious but widely held ideas serve as the basis for consequential policy decisions. ${ }^{2}$ In this note, I examine one such idea, namely that expected inflation is a key determinant of actual inflation. Many economists view expectations as central to the inflation process; similarly, many central banks consider 'anchoring' or 'managing' the public's inflation expectations to be an important policy goal or instrument. Here, I argue that using inflation expectations to explain observed inflation dynamics is unnecessary and unsound: unnecessary because an alternative explanation exists that is equally if not more plausible, and unsound because invoking an expectations channel has no compelling theoretical or empirical basis and could potentially result in serious policy errors. ${ }^{3}$

\section{WHY DO WE THINK THAT EXPECTATIONS MATTER - AND WHY SHOULD WE CARE IF THEY DO?}

'I'm always a little dubious about an appeal to expectations as a causal factor; expectations are by definition a force that that you intuitively feel must be everpresent and very important but which somehow you are never allowed to observe directly.'

R.M. Solow, 'What we know and don't know about inflation' (1979, p. 40)

The usual argument for viewing expected inflation as a key driver of actual inflation goes something like this:

1. Theoretical models (such as those developed by Phelps, Friedman, and Lucas, along with the more recent New Keynesian Phillips curve) all incorporate a role for expected inflation that is either intuitively appealing (because it rules out a state of persistent money illusion) or microfounded in a sensible way (in that the presence of sticky prices should induce a concern about future costs or demand conditions).

2. Models like these also help us explain the observed instability of the Phillips curve and changes in measured inflation persistence over time, especially the US inflation experience from the late 1960s through the mid 1980s and the shift toward a mean-reverting inflation process that appeared to take place around the mid 1990s.

3. In light of the strong prior induced by theory, and with the casual empiricism of point 2 (coupled with the formal empiricism obtained from tests of the New Keynesian inflation equation), it seems sensible to grant a central role for inflation expectations in inflation determination.

2. I leave aside the deeper concern that the primary role of mainstream economics in our society is to provide an apologetics for a criminally oppressive, unsustainable, and unjust social order.

3. I will have nothing to say about what determines inflation expectations - either in principle, or in the context of the various survey and financial market measures that we can observe. (My hope is that any readers who finish this note will no longer find that question terribly interesting.) 
If correct, such a view has important practical and policy consequences. For an inflation forecaster, observed (imperfect) measures of expected inflation might usefully inform inflation projections and permit one to explain past inflation developments. For a central bank with a price-stability mandate, monitoring measures of inflation expectations can provide an important gauge of how well the monetary authority is meeting its goal, while attempts to shape the public's inflation expectations through central-bank communications and policy actions will represent time well spent. In particular, to the extent that post-1990 inflation dynamics reflect the effect that the conduct of monetary policy has had on inflation, there should be an active attempt by policymakers to preserve the relevant features of this policy regime. But what real evidence do we have for this view?

\section{HOW STRONG IS THE THEORETICAL CASE?}

'Pure economics has a remarkable way of pulling rabbits out of a hat-apparently a priori propositions which apparently refer to reality. It is fascinating to try to discover how the rabbits got in; for those of us who do not believe in magic must be convinced that they got in somehow.'

J.R. Hicks, Value and Capital (1946, p. 23)

Two of the earliest theoretical arguments for assigning an explicit role for inflation expectations in a Phillips curve relation are found in Phelps (1967) and Friedman (1968). In addition, Lucas and Rapping (1969) derived an aggregate-supply function in which a correlation between inflation and real activity would arise through a price-expectations mechanism, while Lucas's imperfect information model (which was described opaquely in a 1972 article and somewhat more accessibly in a 1973 paper) implied an inflation equation in which a change in (rationally) expected inflation would pass through onefor-one into the intercept of the Phillips curve. Finally, a later generation of rational expectations models that started from the assumption of less than fully flexible prices or wages gave rise to the so-called New Keynesian Phillips curve, which differed from previous models in assigning a role to the current expectation of the next period's inflation rate (as opposed to the last period's expectation of the current inflation rate).

What are the merits of each theoretical approach? Phelps simply asserted that the intercept of the Phillips curve would shift one-for-one with expected inflation; to the extent that a theoretical argument was vouchsafed, it was based on the notion that 'the supply of labour [should be] independent of the real and money rates of interest and hence independent of the expected rate of inflation,' as 'otherwise, every steady-state of fully anticipated inflation would be associated with different "levels" of output, employment and the real wage' (Phelps 1967, p. 261). Hence, Phelps's argument was basically founded on the idea that nominal variables should not permanently affect real variables, though here the real variable in question was the real interest rate.

Friedman's derivation was superficially simpler than Phelps's - unlike the latter's paper, Friedman's paper contains no equations - but was arguably better grounded in theory. Specifically, Friedman posited that workers entered the wage bargain with a concern over anticipated real wages (the concern with real wages is of course a reasonable one if money illusion is absent) while firms' hiring decisions were based on actual real wages (no distinction was made between the consumption and product wage). Hence, by reducing the ex post real wage, a surprise increase in prices could yield higher employment. But a fully anticipated price increase would be fully reflected in nominal wages, thereby leaving the real wage (or any other real variable) unchanged. 
Lucas and Rapping formulated a model in which price expectations affect labor supply by influencing households' substitution between goods and leisure across time. Specifically, the model assumes that a rise in (expected) real interest rates boosts labor supply today (the cost of current leisure, in terms of foregone future consumption, goes up). Critically, the model also assumes adaptive expectations in the price level, along with less than one-for-one adjustment in nominal interest rates.

A little later, Lucas (1972) constructed a model in which agents use observed market prices in order to assess how much of a given disturbance is 'purely monetary' as opposed to having resulted from a shock to a real variable. The basic idea is tied to the notion that producers might mistake an absolute (money) price change for a relative price change; the theoretical problem that the paper attempts to solve is why one producer's mistake in a particular direction isn't simply offset in the aggregate by a different producer's mistake in the opposite direction. (The paper does so by appealing to a sort of 'islands economy' that is similar to a modeling strategy employed by Phelps in other work.) What is often called the 'Lucas supply function' or 'Lucas surprise supply function' refers to an aggregate supply or Phillips curve relation of this form. ${ }^{4}$

Finally, the subsequent development of the New Keynesian Phillips curve represented an attempt to integrate rational expectations into a model where some sort of exogenously specified contracting mechanism or the assumed presence of adjustment costs yielded nominal rigidities. Given the models' assumed competitive structure, these nominal rigidities would in turn cause current inflation to depend on expected future inflation. ${ }^{5}$

Even without appealing to empirical arguments (that will be done in the following section), it is clear that none of these models makes a strong or even especially plausible theoretical case for including expected inflation in an inflation equation.

- The Phelps assumption is essentially ad hoc; taken literally, Phelps's justification for it requires ignoring effects that fully anticipated inflation can have on current real income (for example, through capital losses on wealth) as well as on perceived permanent income, either of which should affect labor supply to the extent that leisure is a normal good.

- Friedman's derivation assumes that firms are always on their labor demand curve even though workers are not on their labor supply curve, which is a knife-edge case that implicitly assumes that the goods market always clears.

- Both the Phelps and Friedman assumptions can be viewed as trying to ensure that money illusion is absent, that purely nominal disturbances cannot have permanent real effects on the economy, or both. ${ }^{6}$ These are, of course, a priori assumptions that rule out the possibility of path dependence in the economy (for example,

4. Though not as far as Lucas himself is concerned: he views the 'Lucas supply function' as equivalent to the Lucas-Rapping model (see the introduction to Lucas 1981).

5. In fairness, motivating a role for expected inflation was not really the original concern of these models; rather, their goal was to show that a nominal shock could yield persistent real effects under rational expectations. That said, I suspect that one reason why some (not all) economists reared on the Phelps-Friedman tradition were mostly willing to accept the New Keynesian Phillips curve was because the presence of an expected inflation term in the New Keynesian inflation equation resembled something that they already found reasonable when thinking about inflation dynamics.

6. Even if one does think that monetary neutrality is a feature of the real world, it would be an example of Aristotle's 12th logical fallacy (affirming the consequent) to argue that the presence of monetary neutrality therefore necessarily implies a role for expected inflation in price or wage determination. 
hysteresis effects in the labor market); that money illusion or inflation insensitivity could actually exist at low rates of inflation; the effects that high rates of inflation might have on the economy's supply side (a possibility that Friedman 1977 himself acknowledged and that is a prediction of a class of sticky-price models with non-zero steady-state inflation); or the possibility that the economy might function more smoothly at non-zero rates of inflation. ${ }^{7}$

- On a deeper level, both the Phelps and Friedman approaches are grounded in the idea that there is a 'real side' of the economy that eventually makes its influence felt after any sort of (nominal) disturbance, which again falls prey to Fisher's (1983) criticism that there exists no compelling theoretical proof of the stability (as opposed to the existence) of a general economic equilibrium. ${ }^{8}$

- The Lucas-Rapping aggregate supply model hinges on the assumption that expected inflation declines when there is an unanticipated increase in current inflation (this assumption, which in turn only obtains because of the specific adaptive expectations formulation that they employ, is what causes the real interest rate to increase) ${ }^{9}$

- The usual criticism leveled against the Lucas surprise model is that it should not be all that difficult to determine whether there has been a change in the absolute price level (apparently there exist freely available statistics on that sort of thing); also, the model's prediction that only random and transitory policy shocks can affect output seems unappealing on a priori grounds.

- Finally, the channel through which expected inflation enters the New Keynesian Phillips curve is especially contrived. In the canonical version of these models, the nature of the contracting mechanism is such that producers are required to supply as much output as is demanded at the fixed contract price. ${ }^{10}$ Given the imperfectly competitive market structure of these models, firms are therefore concerned with their current and expected real (that is, relative) price, since a future decline in their relative price will result in additional demand that could be less profitable to meet at the previously contracted nominal price. When these individual pricing decisions are aggregated, the result is a dependence of current economy-wide inflation on expected future inflation.

It should also be pointed out that all of these models give pride of place to short-run expected inflation, in the sense that current inflation is influenced by a one-period-ahead expectation (the main difference across models is whether the short-run expectation is last period's expectation of the current inflation rate or this period's expectation of

7. See Ascari and Sbordone (2014) for a New Keynesian model where higher rates of (perfectly anticipated) trend inflation act like a negative productivity shock. The second notion, where inflation 'greases the wheels of the labor market,' is usually attributed to James Tobin. 8. For example, Friedman (1968) describes the natural rate of unemployment as 'the level that would be ground out by the Walrasian system of general equilibrium equations.'

9. This flaw was recognized by Lucas and Rapping in their paper, which contains a lengthy (and strained) defense of the notion that this sort of price-level expectation formation is reasonable, along with an appeal to empirical evidence (that basically involves quoting Irving Fisher) to justify their imposed assumption that nominal interest rates would not move in such a way as to leave the real interest rate unchanged following an inflation change.

10. Similarly, models with wage contracts require workers to supply as much labor as is demanded at the contracted wage. Such assumptions violate the principle of voluntary exchange (and common sense). 
next period's inflation rate). ${ }^{11}$ This fact sits uneasily with the observation that in policy circles - at least in the United States - much more attention is paid to long-run inflation expectations, as it is the 'anchoring' of these expectations that is viewed as being the wellspring of desirable economic outcomes and (as an empirical matter) as the source of important changes in US inflation dynamics over the past 50 years (see Yellen 2015 for one example). Moreover, while it turns out to be possible to append an adaptive-learning mechanism to several of these models in order to derive an inflation equation where long-run inflation expectations do play a critical role (see Section 5 below), such a mechanism turns out to carry subtly different policy implications.

\title{
4 HOW STRONG IS THE EMPIRICAL CASE?
}

\author{
'Don't interfere with fairy tales if you want to live happily ever after.' \\ F.M. Fisher, 'The misuse of accounting rates of return: reply' (1984, p. 509)
}

It is an irony of history (or perhaps a testimony to the power of pure thought) that, when Phelps and Friedman sought to justify their proposed theoretical specifications, they were faced with the uncomfortable fact that empirical Phillips curves appeared to be remarkably stable. The sensible explanation that both authors advanced was that this seeming stability was actually the result of existing models' having been estimated over a period in which actual and expected wage and price inflation had remained within a relatively narrow range. (Oddly, neither author appealed to the gold standard to make his case.) While one could quibble with the view that inflation (and other influences on inflation, like trend productivity and unemployment) had actually been all that stable over the first part of the twentieth century, there was no question that the sustained inflation increases of the 1960s and 1970s appeared to be associated with outward shifts of estimated Phillips curves. Ex post, these developments were seen as a stunning victory for the prediction that expected inflation was an important determinant of actual inflation. ${ }^{12}$

It is worth noting, however, that the direct evidence for an expected inflation channel was never very strong. Most empirical tests concerned themselves with the proposition that there was no permanent Phillips curve trade-off, in the sense that the

11. Even New Keynesian models that explicitly incorporate time-varying trend inflation rates (usually to allow for the possibility of a change in the monetary authority's inflation target) predict that short-run expectations of inflation will have an important influence on current inflation. 12. More recently, Clarida et al. (2000) have attempted to explain the sub-par macroeconomic outcomes of the late 1960s and 1970s by arguing that the Federal Reserve's failure to adhere to the Taylor principle permitted self-fulfilling expectations of inflation - 'sunspots' - to influence macroeconomic outcomes, while also leaving the economy more susceptible to 'fundamental' shocks. However even if the Federal Reserve's policy reaction function did have this property - a view that has been questioned by Orphanides (2004) and by Sims and Zha (2006), among others the Clarida et al. interpretation of the 1970s stagflation requires that period's food and energy price shocks to have resulted in a large and rapid decline in the level of potential output. (Had non-fundamental inflation shocks been the source of the Great Stagflation, output would have been above potential throughout this period.) Such a decline in potential seems highly unlikely in the case of a food-price shock; in addition, as Blinder and Rudd (2013) discuss, Neoclassical supply theory predicts that the effect on potential output from a shock to energy prices (or other imported commodity prices) is relatively small. 
coefficients on lagged inflation in an inflation equation summed to one. ${ }^{13}$ Relatedly, the invocation of an adaptive-expectations mechanism in numerous theoretical contexts led many to simply associate the presence of lagged inflation terms in empirical Phillips-curve models with a role for 'expectations' in some loose sense. ${ }^{14}$ Perhaps the closest (and, for the time, most econometrically sound) attempt at a direct test was made by McCallum (1976), where he used instrumental variables techniques to assess the role of expected price inflation in a wage equation. ${ }^{15}$ (These techniques are similar in spirit to those employed in the 1990s to estimate New Keynesian models; hence they suffer from the same sorts of problems - discussed below - that attend empirical estimates of those models.)

In addition, the various theoretical models that assumed a role for expected inflation tended to carry other empirical implications that were clearly at variance with the data. For example:

- Friedman's derivation of the expectations-augmented Phillips curve implies that the real product wage should be strongly counter-cyclical (recall that in this model, firms are always assumed to be on their labor demand curves). In particular, Friedman states as a matter of fact that 'selling prices of products typically respond to an unanticipated rise in demand faster than prices of factors of production,' which would in turn imply the empirical prediction that the price Phillips curve is steeper than the wage Phillips curve. However in US data this prediction is completely at odds with the evidence: conventional price and wage equations imply that the trade-off between wage inflation and activity is much steeper than that for price inflation (put differently, the aggregate real wage is pro-cyclical).

- The Lucas-Rapping model assumes that inflation follows a trend-stationary process (deviations from this assumption lead to a Phillips curve with the 'wrong' sign). In addition, this model cannot yield large fluctuations in real activity (employment) without assuming a large elasticity of intertemporal substitution.

- The Lucas 'surprise' model depends on the arbitrary exclusion of the current aggregate price level from the information set. More directly, Ball et al. (1988) argue that a key prediction of this model - specifically, that the standard deviation of inflation should matter for the size of the output-inflation trade-off - receives no support in the data.

13. Empirically, this unit sum became easy to find around the mid 1970s - see Gordon (1976) for a contemporaneous account, and McCallum (1994) for a retrospective one. It should also be noted, however, that King and Watson argued as late as 1994 (see King and Watson 1994a) that it was surprisingly difficult to reject the hypothesis of no long-run trade-off in US data without simply imposing it through the 'Monetarist' assumption that 'long-run inflation is a strictly monetary phenomenon' (King and Watson 1994b, p. 245), though see Evans (1994) for an alternative view.

14. It is another irony of history that one of the earliest uses of adaptive expectations in empirical work was not in the context of a model of 'normal' inflation dynamics, but rather in Cagan's (1956) hyperinflation study.

15. Several other studies from the 1970s and 1980s tried to use survey-based or commercial inflation forecasts to disentangle the separate roles of 'inertia' and 'expectations' in union wage-setting; see Kaufman and Woglom (1984) for one example as well as for a useful literature review. (As one might expect from the vantage of hindsight, the Kaufman-Woglom paper found 'surprisingly small' differences between specifications that used 'direct' expectations measures and specifications that simply used lagged actual inflation.) 
Similarly, the documented empirical deficiencies of the New Keynesian Phillips curve are legion.

- The canonical New Keynesian inflation equation implies a long-run trade-off between the output gap and inflation. Attempts to remedy this problem by simply imposing a zero long-run trade-off either imply that real developments millions of years in the future have the same effect as developments today or that inflation is mostly governed by sunspots; or they yield the counter-factual prediction that the first difference of inflation is strongly positively autocorrelated. ${ }^{16}$

- In addition, most standard tests of the New Keynesian Phillips curve suffer from such severe potential misspecification issues or such profoundly weak identification problems as to provide no evidence one way or the other regarding the importance of expectations (much the same statement applies to empirical tests that use survey measures of expected inflation). ${ }^{17}$

- Versions of the New Keynesian model that allow for time-varying trend inflation imply that the effect of real activity on inflation should be smallest in periods such as the 1970s, when trend inflation is high (see Ascari and Sbordone 2014). However, as shown in Figure 1, the response of price inflation following a shock to real activity was largest in the 1970 s, and smaller thereafter. ${ }^{18}$ Furthermore, as the accompanying table indicates, this finding also obtains if we focus on the short-run inflation response: integral multipliers for the fouror eight-quarter period following the shock also become smaller after the 1970s. ${ }^{19}$

- Finally, versions of these models that impose realistic contracting mechanisms (specifically, models that require labor markets to be characterized by voluntary exchange) look very different from the canonical model and do extremely poorly in fitting the data (see Huo and Ríos-Rull 2020).

16. See Rudd and Whelan (2006) for a discussion of the latter point in the context of a 'hybrid' New Keynesian Phillips curve. The dependence on far-future events arises in the 'pure' New Keynesian Phillips curve when a unit coefficient on $E_{t} \pi_{t+1}$ is imposed because each expected future output-gap term in the closed-form solution makes the same contribution to current inflation; alternatively, a role for sunspots arises because the terminal inflation term in the closed form never vanishes.

17. See Rudd and Whelan (2005) for a discussion of the misspecification issue. The weak identification issue affects the hybrid New Keynesian Phillips curve (and was one of several motivations for the alternative tests of the model that Rudd and Whelan 2006 considered); it arises because the variables that are used to instrument for expected future inflation $E_{t} \pi_{t+1}$ will only be able to tie down the influence of this term if a large portion of the predictable variation in inflation is unrelated to lagged inflation. (See Mavroeidis et al. 2014 for a detailed discussion of the estimation issues that arise as a result.)

18. These estimates are obtained from vector autoregression (VAR) models with time-varying parameters and stochastic volatility, and are taken from Peneva (2019); see Peneva and Rudd (2017) for a detailed discussion of the estimation procedure and data. Impulse responses for labor costs - also found in Peneva (2019) - imply a much greater degree of stability for the wage Phillips curve (a finding that is also obtained using conventional empirical wage equations).

19. The integral multipliers are defined as the ratio of the cumulated $n$-quarter impulse response of price inflation to the cumulated $n$-quarter response of the unemployment gap. Calculations such as these are useful because they account for any time variation in the response of the unemployment gap. 


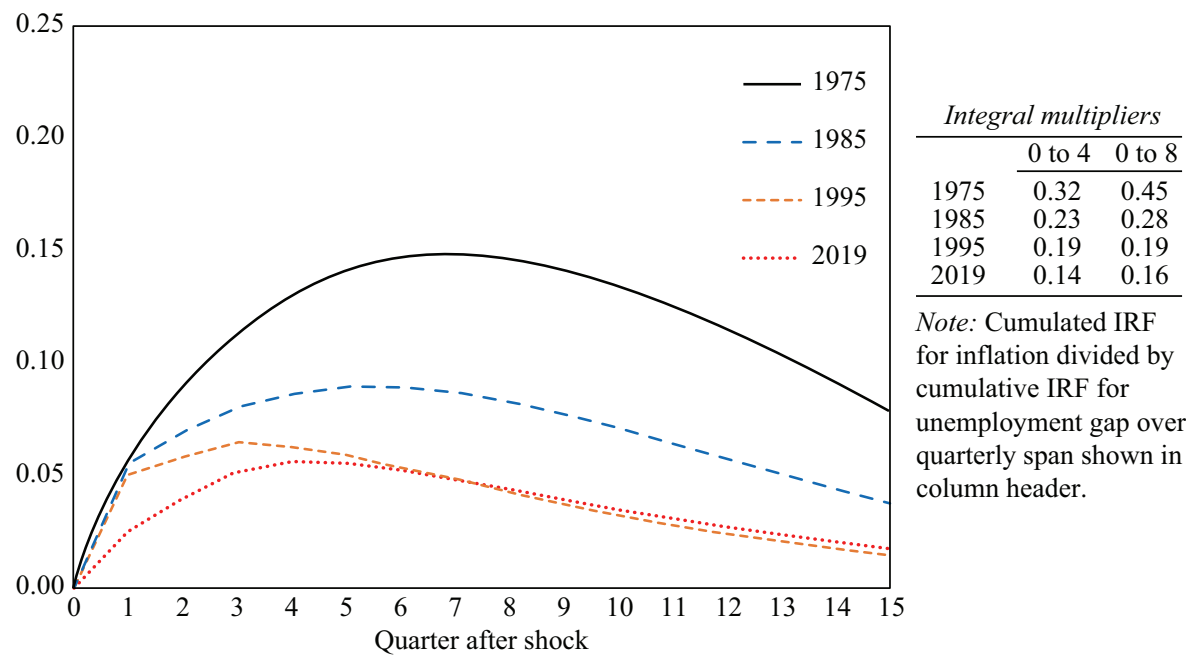

Note: Percentage point deviation from baseline; core inflation defined using market-based PCE price index.

Figure 1 Response of core inflation to an unemployment gap shock

Leaving aside the results of econometric tests of particular models (and given that there is good evidence that many prices actually are sticky), doesn't it seem intuitively plausible that firms fixing their prices over some period would worry about future costs or demand conditions - that is, about any relevant developments that could materialize over the period in which their price is held constant? Perhaps, but perhaps not.

- What little we know about firms' price-setting behavior suggests that many tend to respond to cost increases only when they actually show up and are visible to their customers, rather than in a pre-emptive fashion (see Blinder et al. 1998).

- Similarly, the idea that sticky prices would necessarily result in a dependence of aggregate inflation on aggregate expectations seems a little unintuitive: most of the observed variation in prices appears to be idiosyncratic (suggesting that cost increases are as well), and it seems likely that price stickiness itself is endogenous (in that firms that face relatively more stable costs are more likely to enter into 'fixprice' arrangements).

- It is highly unlikely that something like a Dixit-Stiglitz competitive structure where everyone competes with everyone else to some extent - actually exists; rather, competition for inputs or customers probably has an important local or industry-specific aspect. That would tend to weaken the need for firms to be focused on their future real prices (defined relative to the economy-wide price level), which is how expectations of aggregate inflation enter the New Keynesian Phillips curve. ${ }^{20}$

- Finally, even if one is willing to entertain the idea that in some vague, mushy sense, concern over costs and demand by individual firms facing fixed prices leads to a dependence of aggregate inflation on expected inflation, we are still left with the conclusion that short-run expectations should be the ones that are most important.

20. Unsurprisingly, what little evidence we have suggests that firms pay little attention to forecasts of aggregate economic conditions, including inflation (Blinder et al. 1998). 
This last point is particularly important given that one of the few shreds of empirical evidence that we do have suggests that it is long-run expectations that are most relevant for inflation dynamics. As Figure 2 demonstrates, there is a suggestive low-frequency correlation between an estimate of inflation's long-run stochastic trend and survey measures of long-run expected inflation. ${ }^{21}$ The stability of inflation's longrun trend after the mid 1990s - more precisely, the fact that the trend appears almost completely invariant to changes in economic conditions - is perhaps the most remarkable feature of the US inflation process at present; at a minimum, it represents a significant departure from the experience of the 1970s and 1980s (see the dashed line in Figure 3, which plots the stochastic trend for price inflation over a longer period). ${ }^{22}$

Of course, the correlation that is apparent in Figure 2 provides, at best, only circumstantial evidence of a causal relationship in which expectations determine the long-run properties of inflation; it could equally well reflect a situation where respondents to these surveys are making reasonably plausible inflation forecasts in response to observed changes in actual inflation. In addition, further evidence against a causal relationship is provided by the fact that, in recent years, movements in these survey measures (as well as in long-run inflation expectations from TIPS yields) appear not to be mirrored by changes in trend inflation (this casual observation is confirmed by Rudd 2020 using more-formal estimation techniques). ${ }^{23}$

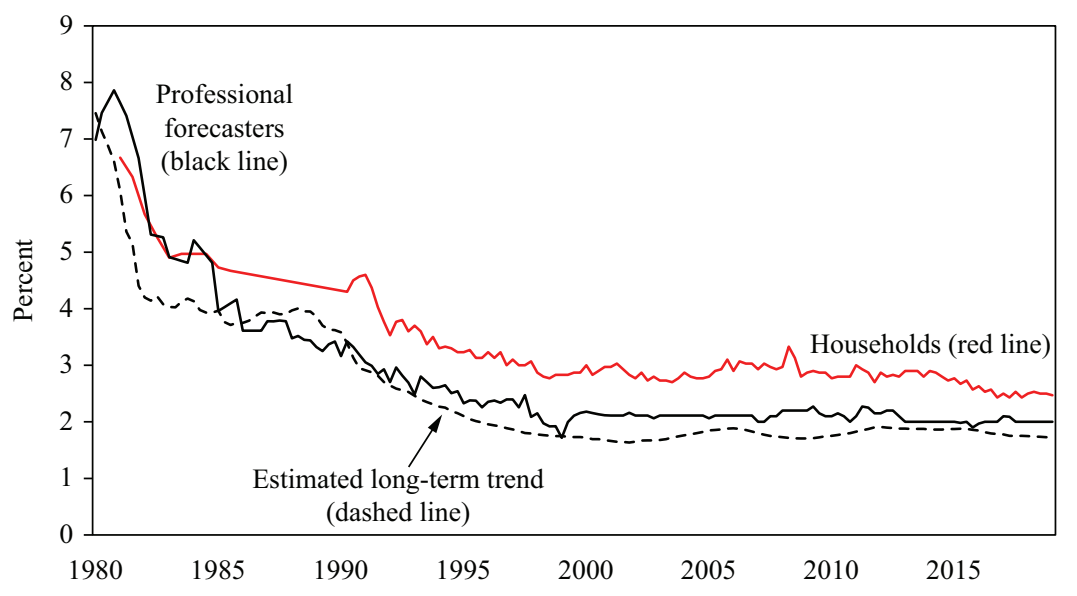

Note: Household expectations are median long-term expectations from the University of Michigan Surveys of Consumers. Expectations for professional forecasters are derived from the Survey of Professional Forecasters (Federal Reserve Bank of Philadelphia).

\section{Figure 2 Long-term inflation expectations and long-term trend inflation}

21. The trend estimate is obtained from the VAR model used for Figure 1.

22. See Peneva and Rudd (2017) and Rudd (2020) for discussions of these points.

23. The characterization of inflation dynamics implied by the flattening of the price Phillips curve and the near-constancy of inflation's long-run trend imply an explanation for the so-called 'missing disinflation' of the late 2000s that is drastically different - but much more plausible than the one advanced by Coibion and Gorodnichenko (2015). In particular, that study starts 


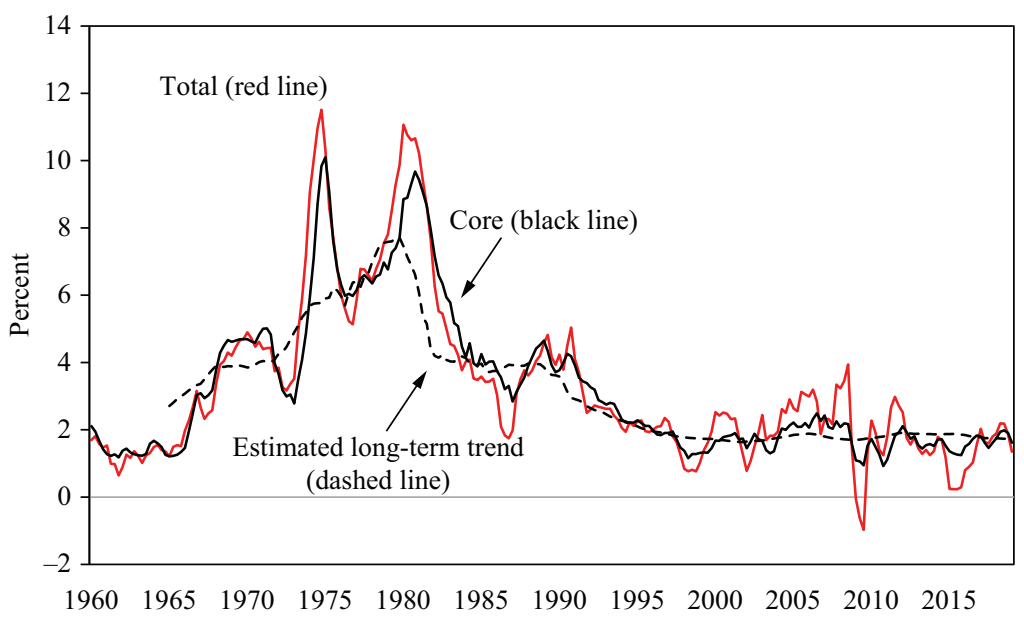

Note: Inflation computed as a four-quarter percent change.

\section{Figure 3 Total and core PCE price inflation since 1960}

A reasonable reader's reaction to the preceding discussion might be: 'So what? No model is going to describe reality all that well, and a convincing theory of aggregate supply - or of inflation dynamics generally - has eluded students of macroeconomics since the field's inception. So your criticisms really just amount to ill-tempered pettifogging.'

What I believe such a response misses is that the presence of expected inflation in these models provides essentially the only justification for the widespread view that expectations actually do influence inflation. In other words, rather than simply serving as a plausible postulate that, once invoked, allows a theorist to analyse other interesting questions, the expected inflation terms in these models have been reified into a supposed feature of reality that 'everyone knows' is there. And this apotheosis has occurred with minimal direct evidence, next-to-no examination of alternatives that might do a similar job fitting the available facts, and zero introspection as to whether it makes sense to use the particular assumptions or derived implications of a theoretical model to inform our priors (particularly when the ancillary assumptions of the model are so incredible and when the few clear predictions it makes are so wildly at odds with the available empirical evidence).

from a price Phillips curve that imposes a unit coefficient on lagged inflation (or on a measure of short-run expected inflation that is closely related to lagged inflation). As a result, the inflation equation that they use, which is essentially an accelerationist Phillips curve, ignores the empirical fact that inflation essentially became a mean-reverting process after the mid 1990s. As Peneva and Rudd (2017, p. 1798) note, such a model of inflation 'generates a misleading benchmark for how we would have expected inflation to behave following the 2007 business cycle peak.' 


\section{AN ALTERNATIVE INTERPRETATION OF INFLATION DYNAMICS}

'It is far, far better and much safer to have a firm anchor in nonsense than to put out on the troubled seas of thought.'

John Kenneth Galbraith, The Affluent Society (1958, p. 130)

If expected inflation isn't a key determinant of actual inflation, how might we try to explain the observed evolution of post-war US inflation dynamics?

First, consider Figure 4, which plots inflation's stochastic trend (the black dashed line) together with the estimated stochastic trend for unit labor cost growth (the gray solid line). ${ }^{24}$ The similar contours of the two lines certainly seems to indicate that the long-run behavior of price inflation and labor cost growth is linked.

Second, the fact that inflation's stochastic trend manifests its last persistent level shift after the 1990-1991 recession also seems relevant, in that it suggests that 'whatever happened' to inflation might be more related to its actual level's having been kept low rather than to any 'credibility' that the Federal Reserve gained as an inflation fighter following the Volcker disinflation. Put differently, a trend inflation rate of around 4 percent was associated with highly persistent inflation dynamics - both in the late 1960s and in the 1980 s - while a 2 percent trend inflation rate was not.

Another way of stating this point is that an important feature of inflation dynamics after the mid 1990s appears to be the lack of a strong wage-price spiral (or of any significant year-to-year feedback between wage growth and inflation). This is true despite large (but ultimately transitory) increases in actual inflation - for example, headline personal-consumption expenditures (PCE) inflation averaged 3 percent over the

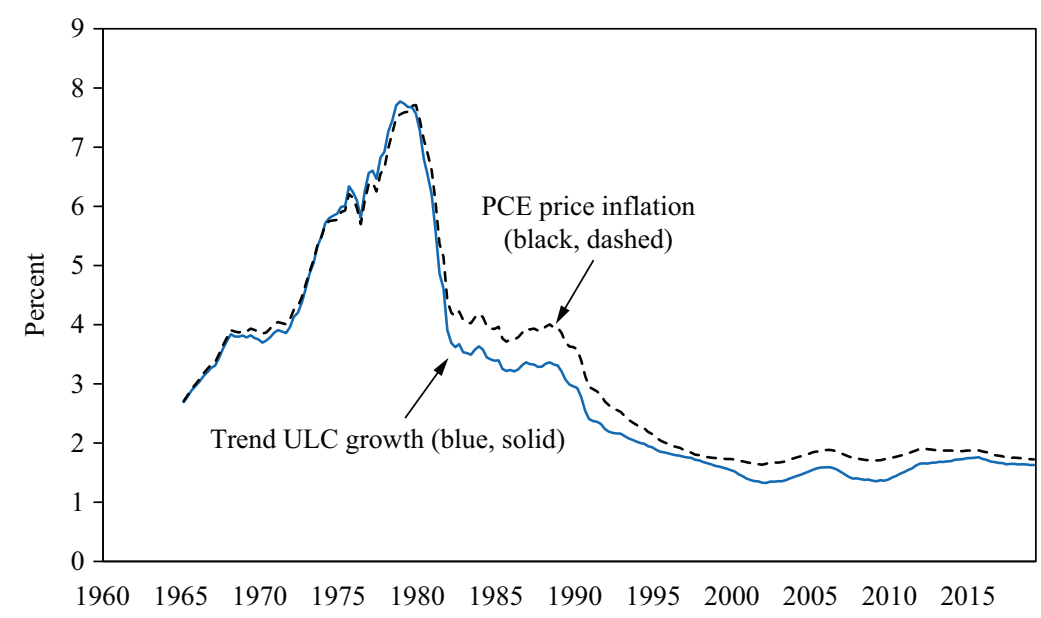

Figure 4 Stochastic trends for PCE price inflation and trend unit labor cost growth

24. More precisely, the measure shown is for 'trend' unit labor cost growth, which uses a measure of trend productivity growth (obtained separately with a bandpass filter) in lieu of actual productivity growth - see the data appendix of Peneva and Rudd (2017) for details. Hence, the line in the figure is the stochastic trend for trend unit labor cost growth. 
three years leading up to the 2007-2009 recession. ${ }^{25}$ It seems unlikely that wellanchored long-run inflation expectations were the root cause of this stability, inasmuch as this belief also leads to the conclusion that workers were willing to ignore noticeable (and reasonably sustained) changes in the cost of living when deciding on the wage rate that they were willing to accept, simply because they believed that eventually inflation would return to some long-run average pace. ${ }^{26}$

An observation about the actual nature of the 'wage-bargaining process' is helpful at this point. Outside of a few unionized industries (which now account for only about 6 percent of employment), a formal wage bargain - in the sense of a structured negotiation over pay rates for the coming year - doesn't really exist anymore in the United States. In a world where most employment is 'at will,' changes in the cost of living will enter nominal wages as part of an employer's attempt to retain workers: if employers pay their workers a wage that falls too far behind the cost of living, they will start to see more quits, which will in turn force them to raise the wages they pay to existing workers (and those they offer to new hires). But there is no real scope for direct negotiation. ${ }^{27}$

In situations where inflation is relatively low on average, it also seems likely that there will be less of a concern on workers' part about changes in the cost of living that is, a smaller proportion of quits will reflect workers' attempts to offset higher consumer prices by finding a better-paying job. But this is a story about outcomes, not expectations: workers don't behave this way because they expect to see low inflation in the future, but rather because they don't view their recent wage increases as appreciably lagging actual changes in the cost of living. ${ }^{28}$

On this latter point the experience of the 1960s and 1970s is telling. As one study of wage determination over this period argued, 'there appears to be some threshold at which the rate of change in living costs becomes a pervasive factor of which account has to be taken in wage decisions' (Douty 1975, p. 6), and that '[i]t is when the upward movement of prices quickens, and extends substantially throughout the whole range of consumer goods and services, that wages begin to respond directly to price movements' (ibid., p. 9). That threshold was apparently reached around the mid 1960s, when the rate of increase in the consumer price index (CPI) moved up to around 3

25. We can make a reasonable case that reactions of labor costs to actual inflation were an important feature of the inflation process in the 1970s. In particular, without this channel's being present, it is nearly impossible to explain why movements in food prices left a durable imprint on core inflation - unlike energy, which can plausibly be viewed as a broader input to industry, changes in agricultural prices shouldn't act like a cost shock to firms outside the food sector.

26. On the other hand, perhaps people actually do expect (say) that a period of 3 percent inflation will be followed by a corresponding interval of 1 percent inflation, leaving the five-to-tenyear average around 2 percent. But I doubt it.

27. Likewise, the survey evidence on why people dislike inflation reported in Shiller (1997) indicates that a major concern is that their wages won't keep up with price increases - which certainly doesn't suggest that they view themselves as having much bargaining power with their existing employer.

28. Similarly, firms might also still be very concerned with their costs, but a relatively small portion of these costs will co-move with economy-wide inflation (beyond those induced by changes in import prices) given that wages are not closely tied to actual inflation and given that - with the exception of labor and imports - one firm's input-cost increase is another firm's output-price increase. 
percent, with 'the advance extending to most of its components' and with the food-athome component rising by 5 percent (ibid., p. 9) ${ }^{29}$

Hence, the current (post-1995) state of inflation dynamics could reflect a situation where inflation simply does not enter workers' employment decisions: people no longer (or don't often) quit a job because their wages aren't keeping up with the cost of living (which is not to say that they won't do so if they believe that they can get higher pay elsewhere - money is money, after all - and especially when conditions in the labor market reduce the likelihood of undergoing a prolonged spell of unemployment before finding a better-paying job). This situation is different from one where an adaptive-expectations channel is operative: under the alternative interpretation, expectations are irrelevant in the sense that there is no attempt to leapfrog or make up for anticipated inflation 'in advance' by negotiating a higher nominal wage. Rather, the current period represents one in which inflation isn't on workers' 'radar screens' anymore (or is at least only a very tiny blip), which in turn yields an outcome where current price inflation does not respond (much) to past inflation (because inflation is not a major factor in wage determination). ${ }^{30}$

Even if one is not willing to concede that inflation expectations are utterly irrelevant, it is still necessary to explain why it would be that long-run expectations appear to be the ones that pin down actual inflation. It turns out to be possible to come up with an explanation along these lines, but it takes a bit of doing.

First, assume that the 'true' inflation equation has a role for short-run expected inflation (say because these expectations influence wage-setting behavior - or simply take your pick from one of the theoretical models described in Section 3). Specifically, assume that the world is described by a version of a Phelps-Friedman Phillips curve:

$$
\pi_{t}=\beta\left(U_{t}-U_{t}^{*}\right)+(1-\phi) \pi_{t-1}+\phi E_{t-1} \pi_{t}+\zeta Z_{t}+e_{t},
$$

where $\pi_{t}$ denotes inflation, $\left(U_{t}-U_{t}^{*}\right)$ is a measure of real activity (for example, the unemployment gap), $Z_{t}$ is a vector of supply shocks, $e_{t}$ is an error term, and where the relevant expectation is $E_{t-1} \pi_{t}$ (that is, last period's expectation of the time- $t$ inflation rate - a short-run expectations concept). Note also that the coefficient values are such that a permanent change in expected inflation eventually passes through one-forone into actual inflation.

Now assume that agents use the following inflation-forecasting rule to formulate their one-period-ahead inflation expectation:

$$
E_{t} \pi_{t+1}=c_{0, t}+c_{1, t} \pi_{t}
$$

29. This study also finds that contracts concluding in 1974 that did not contain explicit escalation clauses tended to see larger average wage increases over the contract period than did contracts with escalation provisions, and notes that this evidence might be consistent with the idea that anticipated inflation - that is, short-run inflation expectations - might have started to enter into wage contracting around this time. However this evidence is also consistent with the notion that the lack of an explicit escalator provision would introduce an insurance motive into wage agreements; most likely, it reflects the fact that explicit escalator clauses contained caps or other provisions such that only about half of a given increase in the CPI tended to show up as a costof-living adjustment.

30. If this situation sounds like former Federal Reserve chair Alan Greenspan's (2002) definition of price stability as 'an environment in which inflation is so low and stable over time that it does not materially enter into the decisions of households and firms,' that's because it basically is. 
or equivalently (lagging one period),

$$
E_{t-1} \pi_{t}=c_{0, t-1}+c_{1, t-1} \pi_{t-1} .
$$

Here, the presence of the time subscripts on the rule's parameters reflects the possibility that agents might update their forecasting rule over time - for example, if some kind of least-squares learning process were at work where agents revise the parameters of the rule by applying a gain to realized forecast errors. (Absent any forecast errors - or absent forecast errors that are sufficiently persistent or outside a certain range - agents are assumed to keep the coefficients of their forecasting rule fixed.) When the forecasting rule has $c_{1}<1$, so agents assume mean-reversion in inflation, long-run expected inflation at $t-1$ will equal

$$
\pi_{t-1}^{L R}=\frac{c_{0, t-1}}{1-c_{1, t-1}}
$$

(Of course, agents could instead assume that inflation follows a random walk - leaving us with an accelerationist Phillips curve - but in that case, there would not be an interesting distinction between long- and short-run expectations.)

Substituting the forecasting rule (3) into the Phelps-Friedman specification (1) yields

$$
\pi_{t}=\beta\left(U_{t}-U_{t}^{*}\right)+(1-\phi) \pi_{t-1}+\phi\left[c_{0, t-1}+c_{1, t-1} \pi_{t-1}\right]+\zeta Z_{t}+e_{t}
$$

which, after a bit of manipulation (and again using the fact that long-run expected inflation will equal the unconditional mean of the forecasting rule) gives us

$$
\pi_{t}=\beta\left(U_{t}-U_{t}^{*}\right)+\left(1-\phi+\phi c_{1, t-1}\right) \pi_{t-1}+\left(\phi-\phi c_{1, t-1}\right) \pi_{t-1}^{L R}+\zeta Z_{t}+e_{t} .
$$

The expectation of long-run inflation in this sort of world will likely be self-fulfilling: with a zero unemployment gap and no supply shocks, actual average inflation will equal the long-run mean obtained from the inflation forecasting rule.

If correct, such a description of the world would carry two important implications:

- First, even though the underlying pricing equation depends on short-run expected inflation, the full inflation equation that obtains will manifest a dependence on long-run expected inflation and actual past inflation (with coefficients that sum to one). Moreover, if agents continue to update their forecasting rule, both long-run expected inflation and inflation's long-run mean will themselves be time-varying. ${ }^{31}$

- By contrast, if this updating process were to stop - for example, if in a learning framework the gain on realized forecast errors were to go to zero - then long-run expected inflation (and inflation's estimated stochastic trend) would be constant.

What this second point suggests is that the observed stability of both observed longrun inflation expectations and inflation's stochastic trend is consistent with a situation in which agents no longer update their perceived law of motion for inflation (put differently, a gain close to zero will weaken the statistical evidence for a unit root in

31. If agents only update the intercept of the forecasting rule (but not their assessment of inflation persistence), the coefficients on $\pi_{t-1}$ and $\pi_{t-1}^{L R}$ in equation (6) will be constant. 
actual inflation). This state of affairs will in turn be reasonable so long as the forecast errors that result from setting expectations in this manner are relatively small - or, if large, not very persistent. It also doesn't preclude continued attention to inflation on the part of households - they are still making forecasts - but, rather, requires them to see no pressing need to revise or update the 'parameters' of their forecasting rule. Finally, a situation like this is also not at odds with actual inflation developments playing a limited role in workers' employment decisions, since 'on average' a steady rate of nominal wage increases (even one that implies a pace of real wage increases that lags trend productivity growth) will still ensure that workers' earnings won't fall too far out of line with the cost of living.

Importantly, this explanation lines up with another salient fact: agents - specifically households - still appear to pay attention to inflation in other contexts. In particular, there is a strong correlation between consumer sentiment and actual inflation, even since the mid 1990s; likewise, actual inflation appears to influence short-run expected inflation (and even long-run expected inflation to a more limited degree). ${ }^{32}$ Again, these observations are consistent with the notion that agents see no reason at present to make large changes to their view of the inflation process ("updates to their forecasting rule'), but they also hint at the mildly disturbing possibility that inflation might not be quite as far off households' radar screens as we might hope. ${ }^{33}$

\section{POSSIBLE PRACTICAL IMPLICATIONS}

\section{'Few things are harder to put up with than the annoyance of a good example.'}

Mark Twain, The Tragedy of Pudd'nhead Wilson (1892, p. 246)

At present, an inflation analyst generating inputs to policy decisions should be mainly concerned with the possibility that inflation's stochastic trend is once again starting to react to changes in actual economic conditions, as such a situation could be a harbinger of a return to a regime with high inflation persistence. However, if the preceding description of inflation dynamics is correct, movements in measures of short-term or long-term expected inflation will probably not provide a very accurate real-time indicator of whether this situation is starting to emerge - and, by extension, whether actual inflation is starting to become a material factor in agents' decisionmaking. ${ }^{34}$

32. The relationship between consumer sentiment and inflation is a well-known and longestablished stylized fact among consumption forecasters, as is the relationship between sentiment and measures of real activity and household wealth. (Of some possible interest for thinking about wage determination, there does not appear to be an economically or statistically significant relationship between changes in the quit rate and changes in inflation over the past 20 years.) 33. What these facts seem to be inconsistent with, however, is an explanation based on strict rational inattention: in a standard model of that sort, agents who did not consider information about inflation to be important would simply ignore it completely; by contrast, once they paid attention to it in one context (sentiment), there would be no reason to ignore it in another sphere (employment) unless they found it significantly more difficult to understand or 'process' the implications of changes in inflation in the latter context. It should also be pointed out that the justification given here for the presence of long-run expected inflation in the Phillips curve can't say anything about another important observed change to the inflation process - namely, why the price Phillips curve has flattened over time even though the wage Phillips curve has not. 34. As noted, movements in measures of expected inflation - which even today can be relatively large and persistent - do not appear to contain much (or any) information about inflation's stochastic trend. 
Similarly, statistical estimates of inflation's long-run trend are likely to suffer from the usual endpoint problems that plague filtering exercises. So is there anything else that analysts or policymakers might try to monitor?

One development to watch for would be any evidence that a renewed concern with price inflation was starting to affect wage determination - either in statistical form (for example, if reduced-form models of wage growth that assumed a stable long-run trend were to see errors emerge that appeared to be correlated with actual inflation) or in the form of anecdotes. To the extent possible, we might also try to determine whether quit rates were starting to rise in a manner that was less tied to the state of the labor market and more correlated with consumer price developments, or whether wage increases for new hires were starting to rise appreciably relative to wage increases for workers in continuing employment relationships (the argument being that wages for new hires are more flexible and hence more responsive to economic conditions). Unfortunately, these are developments that would probably only become clear over a span of several years, not over a few months or quarters.

Another practical implication is rhetorical. By telling policymakers that expected inflation is the ultimate determinant of inflation's long-run trend, central-bank economists implicitly provide too much assurance that this claim is settled fact. Advice along these lines also naturally biases policymakers toward being overly concerned with expectations management, or toward concluding that survey- or market-based measures of expected inflation provide useful and reliable policy guideposts. And in some cases, the illusion of control is arguably more likely to cause problems than an actual lack of control.

\section{POSSIBLE POLICY IMPLICATIONS}

\section{'Interviewer: "What was your intention?" \\ R. Crumb: "I don't know. I think I was just being a punk.",}

Thomas Maremaa, 'Who is This Crumb?' (1972)

Related to this last point, an important policy implication would be that it is far more useful to ensure that inflation remains off of people's radar screens than it would be to attempt to 're-anchor' expected inflation at some level that policymakers viewed as being more consistent with their stated inflation goal. ${ }^{35}$ In particular, a policy of engineering a rate of price inflation that is high relative to recent experience in order to effect an increase in trend inflation would seem to run the risk of being both dangerous and counter-productive inasmuch as it might increase the probability that people would start to pay more attention to inflation and - if successful - would lead to a period where trend inflation once again began to respond to changes in economic conditions. ${ }^{36}$

35. Even if a policymaker's target for actual inflation is informed by a carefully determined 'optimal' level of inflation, it seems plausible that the loss to policymakers from having actual inflation persistently average slightly above or below that target would be smaller than the loss that would obtain (from an overall stabilization standpoint) by having inflation behave in a more persistent, 'accelerationist' manner.

36. Likewise, the single observation that we have suggests that returning to a regime where trend inflation is once again invariant to the state of the economy would be difficult and costly: even the Volcker disinflation wasn't able to achieve this outcome, since inflation's long-run trend persistently moved lower once again after the 1990-1991 recession. 
This sort of concern is not merely academic. Empirical estimates of PCE price inflation's long-run trend typically yield point estimates that are slightly below the Federal Reserve's stated longer-run target of 2 percent (see Rudd 2020). Hence, even if anchored long-run inflation expectations actually are the reason that trend inflation is currently stable, it appears that the level at which they are anchored isn't fully aligned with the Federal Reserve's policy goal.

A related issue is more pragmatic. In some ways, the situation that arises from a focus on long-term inflation expectations is similar to one in which a policymaker seeks to target a single indicator of full employment - for instance, the natural rate of unemployment. Like the natural rate, the long-run expectations that are relevant for wage and price determination cannot be directly measured, but instead need to be inferred from empirical models. Hence, using inflation expectations as a policy instrument or intermediate target has the result of adding a new unobservable to the mix. And, as Orphanides (2004) has persuasively argued, policies that rely too heavily on unobservables can often end in tears.

One might also be uneasy about policymakers' relying too heavily on the assumption that inflation's long-run trend will remain stable going forward so long as measured long-run inflation expectations do. Even if every one of my preceding arguments is judged by the reader to be completely unconvincing, it nevertheless remains the case that we have nothing better than circumstantial evidence for a relationship between long-run expected inflation and inflation's long-run trend, and no evidence at all about what might be required to keep that trend fixed (beyond that it might involve keeping actual inflation from moving up too much above 2 percent on a sustained basis). Given the huge boon to stabilization policy that results from a stable long-run inflation trend, actions that might jeopardize that stability would appear to face an unusually high cost-benefit hurdle.

\section{A CLOSING THOUGHT}

'The best lack all conviction, while the worst Are full of passionate intensity.'

W.B. Yeats, 'The second coming' (1920)

Consider the following Gedankenversuch.

Say you had never heard of Phelps or Friedman, and only knew that the stochastic trend for inflation (and labor costs) last shifted noticeably following a recession that occurred after a period when actual inflation had been running at 4 percent. You then came across some survey measures of long-run expected inflation that roughly showed the same one-time level shift. Would you be convinced enough by this evidence to conclude that long-run inflation expectations were an important factor driving inflation dynamics? Or would you be skeptical of this conclusion because it is basically derived from a single observation (with later observations providing no evidence at all), and because one could just as easily explain these facts with an appeal to the notion that agents were simply making forecasts of inflation that were roughly correct on average? How would you also explain that a recession permanently reduced trend inflation when actual inflation was 4 percent, but never did so thereafter?

Or would you justify the view that expectations 'matter' by pointing to the inflation experience of the 1960s and 1970s, even though that period provides no actual evidence that workers or firms tried to boost their wages or raise their prices in 
anticipation of future price or cost changes? After all, history really only tells us that lags of actual inflation seem to enter inflation equations to a greater or lesser degree over time, not that expectations do or did; thinking that these lags of inflation are present because they are a proxy for some kind of forecast is more a habit of mind than anything solidly grounded in fact.

Alternatively, if you view the theoretical arguments as dispositive, exactly how would you explain to a fellow economist why it is that you see an important role for expected inflation in inflation dynamics? Would you make a halfhearted appeal to Phelps and Friedman? Would you feel a little guilty doing so, knowing that these authors either assumed such a role for expectations (Phelps) or motivated it with a theoretical mechanism whose basic predictions are clearly wrong (Friedman)? If not, then how would you explain that, in reality, only long-run inflation expectations seem even vaguely related to actual inflation? And if you tied your explanation to some sort of 'wage-bargaining' mechanism, what existing institutional feature of the economy would you point to in order to justify it? Would you instead try to fall back on the New Keynesian Phillips curve, whose theoretical derivation is even harder to take seriously and whose empirical justification is close to nonexistent?

And would you feel the slightest bit nervous (or chagrined) about any of it?

\section{REFERENCES}

Ascari, Guido and Argia M. Sbordone (2014), 'The macroeconomics of trend inflation,' Journal of Economic Literature, 52, 679-739.

Ball, Laurence, N. Gregory Mankiw, and David Romer (1988), 'The New Keynesian economics and the output-inflation trade-off,' Brookings Papers on Economic Activity, 1, 1-65.

Blinder, Alan S. and Jeremy B. Rudd (2013), 'The supply-shock explanation of the Great Stagflation revisited,' in Michael D. Bordo and Athanasios Orphanides (eds), The Great Inflation: The Rebirth of Modern Central Banking, Chicago: University of Chicago Press, pp. 119-175.

Blinder, Alan S., Elie R.D. Canetti, David E. Lebow, and Jeremy B. Rudd (1998), Asking About Prices: A New Approach to Understanding Price Stickiness, New York: Russell Sage Foundation.

Brown, Murray (1980), 'The measurement of capital aggregates: a postreswitching problem,' in Dan Usher (ed.), The Measurement of Capital, Chicago: University of Chicago Press, pp. 377-420.

Cagan, Phillip (1956), 'The monetary dynamics of hyperinflation,' in Milton Friedman (ed.), Studies in the Quantity Theory of Money, Chicago: University of Chicago Press, pp. 25-117.

Clarida, Richard, Jordi Galí, and Mark Gertler (2000), 'Monetary policy rules and macroeconomic stability: evidence and some theory,' Quarterly Journal of Economics, 115, 147-180.

Coibion, Olivier and Yuriy Gorodnichenko (2015), 'Is the Phillips curve alive and well after all? Inflation expectations and the missing disinflation,' American Economic Journal: Macroeconomics, 7, 197-232.

Douty, H.M. (1975), 'Cost-of-living escalator clauses and inflation,' Staff Report, Executive Office of the President, Council on Wage and Price Stability, Washington, DC: US Government Printing Office.

Evans, Charles L. (1994), 'The post-war U.S. Phillips curve: a comment,' Carnegie-Rochester Conference Series on Public Policy, 41, 221-230.

Felipe, Jesus and Franklin M. Fisher (2003), 'Aggregation in production functions: what applied economists should know,' Metroeconomica, 54, 208-262.

Fisher, Franklin M. (1983), Disequilibrium Foundations of Equilibrium Economics, Cambridge, UK: Cambridge University Press. 
Fisher, Franklin M. (1984), 'The misuse of accounting rates of return: reply,' American Economic Review, 74, 509-517.

Friedman, Milton (1968), 'The role of monetary policy,' American Economic Review, 58, 1-17.

Friedman, Milton (1977), 'Nobel lecture: inflation and unemployment,' Journal of Political Economy, 85, 451-472.

Galbraith, John Kenneth (1958), The Affluent Society, New York: Houghton Mifflin.

Gordon, Robert J. (1976), 'Recent developments in the theory of inflation and unemployment,' Journal of Monetary Economics, 2, 185-220.

Grandmont, Jean-Michel (1982), Money and Value: A Reconsideration of Classical and Neoclassical Monetary Theories, Cambridge, UK: Cambridge University Press.

Greenspan, Alan (2002), 'Chairman's remarks,' Federal Reserve Bank of St. Louis Review, July/ August, 5-6.

Hammett, Dashiell (1929 [1989]), The Dain Curse, Reprint, New York: Vintage Books.

Hicks, J.R. (1946), Value and Capital: An Inquiry into Some Fundamental Principles of Economic Theory, Second Edition, Oxford: Oxford University Press.

Hildenbrand, Werner (1994), Market Demand: Theory and Empirical Evidence, Princeton, NJ: Princeton University Press.

Huo, Zhen and José-Víctor Ríos-Rull (2020), 'Sticky wage models and labor supply constraints,' American Economic Journal: Macroeconomics, 12, 284-318.

Kaufman, Roger T. and Geoffrey Woglom (1984), 'The effects of expectations on union wages,' American Economic Review, 74, 418-432.

King, Robert G. and Mark W. Watson (1994a), 'The post-war U.S. Phillips curve: a revisionist econometric history,' Carnegie-Rochester Conference Series on Public Policy, 41, 157-219.

King, Robert G. and Mark W. Watson (1994b), 'Rejoinder to Evans and McCallum,' CarnegieRochester Conference Series on Public Policy, 41, 243-250.

Lucas, Robert E., Jr (1972), 'Expectations and the neutrality of money,' Journal of Economic Theory, 4, 103-124.

Lucas, Robert E., Jr (1973), 'Some international evidence on output-inflation tradeoffs,' American Economic Review, 63, 326-334.

Lucas, Robert E., Jr (1981), Studies in Business-Cycle Theory, Cambridge, MA: MIT Press.

Lucas, Robert E., Jr and Leonard A. Rapping (1969), 'Real wages, employment, and inflation,' Journal of Political Economy, 77, 721-754.

Maremaa, Thomas (1972), 'Who is This Crumb?,' New York Times, 1 October.

Mavroeidis, Sophocles, Mikkel Plagborg-Møller, and James H. Stock (2014), 'Empirical evidence on inflation expectations in the New Keynesian Phillips curve,' Journal of Economic Literature, 52, 124-188.

McCallum, B.T. (1976), 'Rational expectations and the natural rate hypothesis: some consistent estimates,' Econometrica, 44, 43-52.

McCallum, Bennett (1994), 'Identification of inflation-unemployment tradeoffs in the 1970s: a comment,' Carnegie-Rochester Conference Series on Public Policy, 41, 231-241.

Orphanides, Athanasios (2004), 'Monetary policy rules, macroeconomic stability, and inflation: a view from the trenches,' Journal of Money, Credit and Banking, 36, 151-175.

Peneva, Ekaterina (2019), Presentation at the Conference 'What's (Not) Up With Inflation?,' Brookings Institution, 3 October, available at: https://www.brookings.edu/wp-content/ uploads/2019/09/Ekaterina-Peneva.pdf (accessed 24 August 2021).

Peneva, Ekaterina V. and Jeremy B. Rudd (2017), 'The passthrough of labor costs to price inflation,' Journal of Money, Credit and Banking, 49, 1777-1802.

Phelps, Edmund S. (1967), 'Phillips curves, expectations of inflation and optimal unemployment over time,' Economica, 34(135), 254-281.

Rudd, Jeremy B. (2020), 'Underlying inflation: its measurement and significance,' Board of Governors of the Federal Reserve System, FEDS Notes 2020-09-18.

Rudd, Jeremy and Karl Whelan (2005), 'New tests of the New-Keynesian Phillips curve,' Journal of Monetary Economics, 52, 1167-1181.

Rudd, Jeremy and Karl Whelan (2006), 'Can rational expectations sticky-price models explain inflation dynamics?', American Economic Review, 96, 303-320. 
Shiller, Robert J. (1997), 'Why do people dislike inflation?,' in Christina D. Romer and David H. Romer (eds), Reducing Inflation: Motivation and Strategy, Chicago: University of Chicago Press, pp. 13-65.

Sims, Christopher A. and Tao Zha (2006), 'Were there regime switches in U.S. monetary policy?,' American Economic Review, 96, 54-81.

Solow, Robert M. (1979), 'What we know and don't know about inflation,' Technology Review, 81(3), 30-46.

Stigler, George J. (1983), 'Nobel lecture: the process and progress of economics,' Journal of Political Economy, 91, 529-545.

Twain, Mark (1892), The Tragedy of Pudd'nhead Wilson, Hartford, CT: American Publishing Company.

Yellen, Janet L. (2015), 'Inflation dynamics and monetary policy,' Remarks Delivered at the Philip Gamble Memorial Lecture, University of Massachusetts, Amherst, 24 September. 